\title{
ESTIMATING MODEL PARAMETER VALUES FOR TOTAL SYSTEM PERFORMANCE ASSESSMENT
}

WILLIAM L. EBERT, VLADISLAV N. ZYRYANOV, JAMES C. CUNNANE CMT Division, Argonne National Laboratory, Argonne, IL 60439, ebert@cmt.anl.go

\section{ABSTRACT}

The intrinsic dissolution rates of nine borosilicate waste glasses were extracted from the results of MCC-1 tests conducted for durations long enough that the solution $\mathrm{pH}$ reached a nearly constant value but short enough that the buildup of dissolved species did not affect the dissolution rate. The effects of the $\mathrm{pH}$ and temperature on the measured rates were deconvoluted to determine the sensitivity of the rate to the glass composition. The intrinsic dissolution rates were similar for all of these glasses and were not correlated with the glass composition. The mean and standard deviation of the intrinsic dissolution rates of these glasses are log $\left\{\mathrm{k}_{0} /\left[\mathrm{g} /\left(\mathrm{m}^{2} \bullet \mathrm{d}\right)\right]\right\}=8.2 \pm 0.2$.

\section{INTRODUCTION}

The results of total system performance assessment (TSPA) calculations will play an important role in the design and licensing of the federal repository for high-level radioactive waste disposal. These calculations will be used to evaluate the long-term containment of radionuclides by the waste forms and the engineered barrier systems and to ensure that regulatory requirements will be met throughout the service life of the disposal system. A mechanistic rate expression has been developed for borosilicate waste glasses and was included in the TSPA-Viability Assessment report [1]. That expression contains terms for the forward dissolution rate $\left(\mathrm{k}_{\mathrm{f}}\right)$, which depends on the glass composition, $\mathrm{pH}$, and temperature, and for the reaction affinity term, which quantifies the feedback effect of solute species on the glass dissolution. The rate expression can be written as:

$$
\text { rate }=\mathrm{S} \bullet \mathrm{k}_{\mathrm{f}} \bullet(1-\mathrm{Q} / \mathrm{K})
$$

where $\mathrm{S}$ is the surface area. The value of the affinity term, which is the term in parentheses, depends on the saturation index of the solution, $\mathrm{Q} / \mathrm{K}$, where $\mathrm{K}$ is a quasi-thermodynamic constant. The forward rate can be written as:

$$
\mathrm{k}_{\mathrm{f}}=\mathrm{k}_{0} \cdot 10^{\mathrm{h} \cdot \mathrm{pH}} \cdot \mathrm{e}^{\left(-\mathrm{E}_{\mathrm{a}} / \mathrm{RT}\right)}
$$

where $\mathrm{k}_{0}, \mathrm{~h}$, and $\mathrm{E}_{\mathrm{a}}$ are parameters for the effects of the glass composition, $\mathrm{pH}$, and temperature on the rate. These parameters values must be measured experimentally. Previous tests have shown the values of $h$ and $E_{a}$ can be assumed to be independent of the glass composition [2-5]. In this paper, we present the results of tests conducted to determine the values of the intrinsic dissolution rate $\left(\mathrm{k}_{0}\right)$ for glass compositions that are representative of likely high-level waste glasses. 


\section{DISCLAIMER}

This report was prepared as an account of work sponsored by an agency of the United States Government. Neither the United States Government nor any agency thereof, nor any of their employees, make any warranty, express or implied, or assumes any legal liability or responsibility for the accuracy, completeness, or usefulness of any information, apparatus, product, or process disclosed, or represents that its use would not infringe privately owned rights. Reference herein to any specific commercial product, process, or service by trade name, trademark, manufacturer, or otherwise does not necessarily constitute or imply its endorsement, recommendation, or favoring by the United States Government or any agency thereof. The views and opinions of authors expressed herein do not necessarily state or reflect those of the United States Government or any agency thereof. 


\section{DISCLAIMER}

Portions of this document may be illegible in electronic image products. Images are produced from the best available original document. 


\section{EXPERIMENTAL METHOD}

The glasses used in these tests include reference compositions for the Defense Waste Processing Facility (DWPF), the West Valley Demonstration Project (WVDP), and Hanford tank wastes. The glass compositions are given in Table 1. The SRL $51 \mathrm{~S}$ glass is a nonradioactive homologue of glass that was made at DWPF with sludge from Tank 51 [6]. The SRL 202U, SRL 165U, and SRL $131 \mathrm{U}$ glasses represent possible DWPF waste glasses. The WV6 glass is a nonradioactive homologue of the glasses made at the WVDP. A glass formulated to represent a potential waste glass made with Hanford tank wastes [7] is also being tested; we refer to that glass as Hanford-D glass. The intrinsic rates of three other glasses were measured to evaluate the effects of high and low aluminum contents: Hanford-L, LD6-5412, and PNL 7668. The glass we refer to as Hanford-L was formulated at BNFL, Inc., as a reference glass for lowactivity waste forms. The LD6-5412 glass is a reference low-activity waste glass for Hanford tank wastes that contains a much higher concentration of aluminum than typical high-level waste glasses. The PNL 7668 glass was included as a composition without aluminum. These glasses were tested to provide added insight regarding the effect of composition on the intrinsic dissolution rate.

The nine glasses used in this study provide a wide range in the concentrations of key glass components, including $\mathrm{Al}_{2} \mathrm{O}_{3}$ from 0 to 13 mass $\%, \mathrm{~B}_{2} \mathrm{O}_{3}$ from 5.3 to 13 mass $\%, \mathrm{Na}_{2} \mathrm{O}$ from 9 to 20 mass $\%$, and $\mathrm{SiO}_{2}$ from 31 to 59 mass $\%$. While the compositions of high-level waste glasses have not been finalized for Hanford tank wastes or for high-level wastes in Idaho, it is likely that the concentrations of the key glass-forming components of the waste form will be within these ranges, and that the intrinsic dissolution rate measured in the present study will provide an upper bound to the intrinsic dissolution rates of waste glasses developed in the future.

The MCC-1 tests [8] were conducted with disk-shaped monolithic specimens nominally $10 \mathrm{~mm}$ in diameter and $1 \mathrm{~mm}$ thick. The faces of the samples were polished to a 600 -grit final finish and cleaned to remove fines. Samples were placed flat on perforated Type 304L stainless steel or titanium stands in Type 304L stainless steel vessels. Enough demineralized water was added to the vessel so that the geometric glass surface area/water volume ratio was about $10 \mathrm{~m}^{-1}$. The vessel was sealed with a Teflon gasket and closure fitting, then placed in a convection oven set at $90^{\circ} \mathrm{C}$ for periods ranging from 1 to 33 days. Blank tests with only demineralized water added to the vessel were conducted for similar durations. At the end of the test, an aliquot of the solution was analyzed for $\mathrm{pH}$ with a combination electrode. The remaining solution was acidified with ultrapure, concentrated nitric acid and analyzed with inductively coupled plasmaatomic emission spectroscopy (ICP-AES).

\section{RESULTS AND DISCUSSION}

The results of the short-term MCC-1 tests are plotted in Figs. 1 and 2 as the normalized elemental mass loss based on the solution concentrations of $\mathrm{B}, \mathrm{Na}$, and $\mathrm{Si}$ against the test duration. The normalized elemental mass loss, NL(i), was calculated using the following expression

$$
\mathrm{NL}(\mathrm{i})=\mathrm{C}(\mathrm{i}) /\{(\mathrm{S} / \mathrm{V}) \bullet \mathrm{f}(\mathrm{i})\}
$$


Table 1. Composition of Reference Glasses, in oxide mass \%

\begin{tabular}{|c|c|c|c|c|c|c|c|c|c|}
\hline Oxide & SRL 51S & $\begin{array}{c}\text { SRL } \\
202 U \\
\end{array}$ & $\begin{array}{c}\mathrm{SRL} \\
165 \mathrm{U} \\
\end{array}$ & $\begin{array}{r}\text { SRL } \\
131 \mathrm{~A} \\
\end{array}$ & $\mathrm{WV}^{\mathrm{a}}$ & $\begin{array}{c}\text { Hanford- } \\
D^{b}\end{array}$ & $\begin{array}{c}\text { Hanford- } \\
\mathrm{L}^{\mathrm{c}}\end{array}$ & $\begin{array}{l}\text { LD6- } \\
5412 \\
\end{array}$ & $\begin{array}{c}\text { PNL 76- } \\
68^{\mathrm{d}} \\
\end{array}$ \\
\hline $\mathrm{Al}_{2} \mathrm{O}_{3}$ & 5.27 & 3.84 & 4.08 & 3.27 & 6.00 & 10.13 & 11.97 & 12.89 & - \\
\hline $\mathrm{B}_{2} \mathrm{O}_{3}$ & 7.41 & 7.97 & 6.76 & 9.65 & 12.89 & 6.99 & 8.85 & 5.34 & 8.98 \\
\hline $\mathrm{CaO}$ & 1.39 & 1.2 & 1.62 & 1.23 & 0.48 & 4.04 & - & 3.90 & 2.54 \\
\hline $\mathrm{Cr}_{2} \mathrm{O}_{3}$ & 0.44 & 0.08 & $<0.01$ & 0.13 & 0.14 & 0.04 & 0.02 & - & 0.43 \\
\hline $\mathrm{Cs}_{2} \mathrm{O}$ & - & - & - & - & 0.08 & - & - & - & 1.06 \\
\hline $\mathrm{Fe}_{2} \mathrm{O}_{3}{ }^{\mathrm{e}}$ & 12.2 & 11.4 & 11.74 & 12.7 & 12.02 & 22.95 & 5.77 & 0.124 & 9.16 \\
\hline $\mathrm{K}_{2} \mathrm{O}$ & 1.39 & 3.71 & - & 3.86 & 5.00 & 0.86 & 3.10 & 1.37 & - \\
\hline $\mathrm{La}_{2} \mathrm{O}_{3}$ & 0.52 & - & $<0.05$ & - & 0.04 & - & - & - & 4.11 \\
\hline $\mathrm{Li}_{2} \mathrm{O}$ & 4.54 & 4.23 & 4.18 & 3.0 & 3.71 & 3.00 & - & - & - \\
\hline $\mathrm{MgO}$ & 1.79 & 1.32 & 0.7 & 1.31 & 0.89 & 0.11 & 1.99 & 0.035 & - \\
\hline $\mathrm{MnO}_{2}$ & 1.41 & 2.21 & 2.79 & 2.43 & 1.01 & 0.41 & - & 0.0047 & - \\
\hline $\mathrm{MoO}_{3}$ & - & 0.02 & $<0.01$ & - & 0.04 & - & - & - & 1.85 \\
\hline $\mathrm{Na}_{2} \mathrm{O}$ & 9.60 & 8.92 & 10.85 & 12.1 & 8.00 & 15.74 & 20.0 & 20.23 & 14.2 \\
\hline $\mathrm{Nd}_{2} \mathrm{O}_{3}$ & - & - & $<0.05$ & - & 0.14 & - & - & - & 1.40 \\
\hline $\mathrm{NiO}$ & 0.26 & 0.82 & 0.85 & 1.24 & 0.25 & 0.10 & - & - & 0.19 \\
\hline $\mathrm{P}_{2} \mathrm{O}_{5}$ & 0.58 & - & 0.023 & - & 1.20 & 0.72 & 0.080 & 0.119 & 0.64 \\
\hline $\mathrm{SiO}_{2}$ & 56.3 & 48.9 & 52.86 & 43.8 & 40.98 & 30.19 & 38.25 & 58.91 & 42.3 \\
\hline $\mathrm{SrO}$ & - & 0.03 & 0.11 & 0.01 & 0.02 & 4.16 & - & - & 0.40 \\
\hline $\mathrm{ThO}_{2}$ & 0.014 & 0.26 & - & - & 3.56 & - & - & - & - \\
\hline $\mathrm{TiO}_{2}$ & - & 0.91 & 0.14 & 0.65 & 0.80 & 0.19 & 2.49 & 0.84 & 2.96 \\
\hline $\mathrm{UO}_{2}$ & 1.1 & 1.93 & 0.92 & 2.73 & 0.59 & - & - & - & - \\
\hline $\mathrm{ZnO}$ & 0.13 & 0.02 & 0.04 & 0.02 & 0.02 & 0.01 & 4.27 & & 3.27 \\
\hline $\mathrm{ZrO}_{2}$ & - & 0.1 & 0.66 & 0.22 & 1.32 & - & 2.49 & 0.0068 & 1.76 \\
\hline
\end{tabular}


where $\mathrm{C}(\mathrm{i})$ is the measured solution concentration, $\mathrm{S} / \mathrm{V}$ is the glass surface area/solution volume ratio, and $\mathrm{f}(\mathrm{i})$ is the mass fraction of element $\mathrm{i}$ in the glass. (The concentrations of $\mathrm{B}, \mathrm{Na}$, and $\mathrm{Si}$ in the blank tests were below detection limit and were neglected in the calculations.) Linear regression lines are drawn through the results in Figs. 1 and 2 to provide graphical measures of the normalized dissolution rates $\mathrm{NR}(\mathrm{B}), \mathrm{NR}(\mathrm{Na})$, and $\mathrm{NR}(\mathrm{Si})$. These were used as estimates of the forward dissolution rate $\left(\mathrm{k}_{\mathrm{f}}\right)$; the origin was not included in the regression fits for any of the glasses. The results of tests conducted for less than two days were not included in the regression fits because (1) they are strongly affected by disturbance of the outer surface by the surface preparation and (2) the solution $\mathrm{pH}$ increased rapidly over the first two days due to the consumption of protons during the initial dealkalization of the surface. While high-energy sites generated during surface preparation are present on all samples, their contribution to the total amount of glass dissolved is expected to become constant for a given glass after the outer surface dissolves. For tests with each glass, the $\mathrm{pH}$ values became nearly constant after the first few days.

The results of tests conducted for longer than about 10 days were excluded from the regression because the dissolution rate was likely affected by the buildup of dissolved glass components. The results of these tests lie below the regression lines drawn through the results of tests conducted for between about two and ten days. The test results for most glasses are well fit by linear regression over the interval of two to ten days; the regression coefficients are $\mathrm{R}^{2}>0.92$. An exception is the results of tests with Hanford-D glass, which show more scatter.

In the plots in Figs. 1 and 2, results shown by solid symbols were included in the linear regression to determine the slope, which is the dissolution rate, while results shown by open symbols were excluded from the regression. The slopes based on the releases of B and $\mathrm{Si}$ and the average solution $\mathrm{pH}$ values for the tests included in the regression analyses were used to calculate the intrinsic dissolution rates. The release of sodium is presumed to occur by ion exchange rather than by matrix dissolution, even though the release rates of $\mathrm{B}, \mathrm{Na}$, and $\mathrm{Si}$ are similar. For convenience, we express Eq. 2 in logarithmic form and solved for $\log \mathrm{k}_{0}$ :

$$
\log \mathrm{k}_{0}=\log \mathrm{k}_{\mathrm{f}}-\mathrm{h} \bullet \mathrm{pH}-\log \left\{\exp \left(-\mathrm{E}_{\mathbf{a}} / \mathrm{RT}\right)\right\}
$$

Although the $\mathrm{pH}$ and temperature dependencies have only been measured for a few glasses [2-5], the values of $h$ and $E_{a}$ are similar for these glasses. For the present analysis, we used $h=0.4$ and $E_{\mathrm{a}}=80 \mathrm{~kJ} / \mathrm{mol}$. The solution $\mathrm{pH}$ was measured at room temperature. The $\mathrm{pH}$ at the test temperature of $90^{\circ} \mathrm{C}$ was assumed to be 1.6 units lower than the $\mathrm{pH}$ measured at room temperature due to the difference in the equilibrium constants of water at 25 and $90^{\circ} \mathrm{C}$. This adjustment to the $\mathrm{pH}$ has the effect of increasing the value of $\log \mathrm{k}_{0}$ by 0.64 and the value of $\mathrm{k}_{0}$ by a factor of 4.4 for all glasses. The temperature-adjusted $\mathrm{pH}$ values were used to calculate the value of the $\mathrm{pH}$ term (i.e., $\mathrm{h} \bullet \mathrm{pH}$ ) at $90^{\circ} \mathrm{C}$, where $\mathrm{h}=0.4$. Since all tests were conducted at $90^{\circ} \mathrm{C}$, the value of the temperature term with $E_{a}=80 \mathrm{~kJ} / \mathrm{mol}$ is -11.51 for all tests. The intrinsic dissolution rates calculated by using Eq. 4 and the normalized dissolution rates based on B and Si are summarized in Table 2.

The average intrinsic dissolution rate of the reference high-level waste glasses is almost the same as the average for all nine glasses. If the higher value of $\log k_{0}(B)$ and $\log k_{0}(\mathrm{Si})$ for each glass is used, the average for all glasses is $\log \left\{\mathrm{k}_{0} /\left[\mathrm{g} /\left(\mathrm{m}^{2} \bullet \mathrm{d}\right)\right]\right\}=8.26 \pm 0.15$ and the percent relative standard deviation is $1.5 \%$. The percent relative standard deviations in the forward rates (for all glasses) are $42 \%$ for $\mathrm{NR}(\mathrm{B})$ and $23 \%$ for $\mathrm{NR}(\mathrm{Si})$. This indicates that most of the 


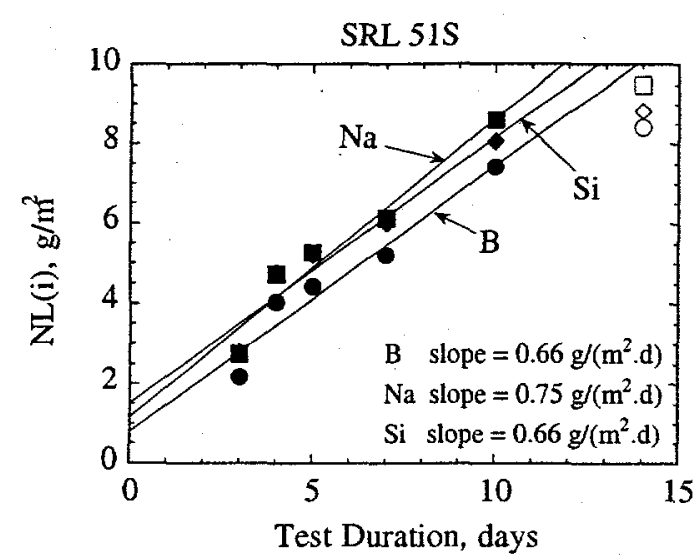

(a)

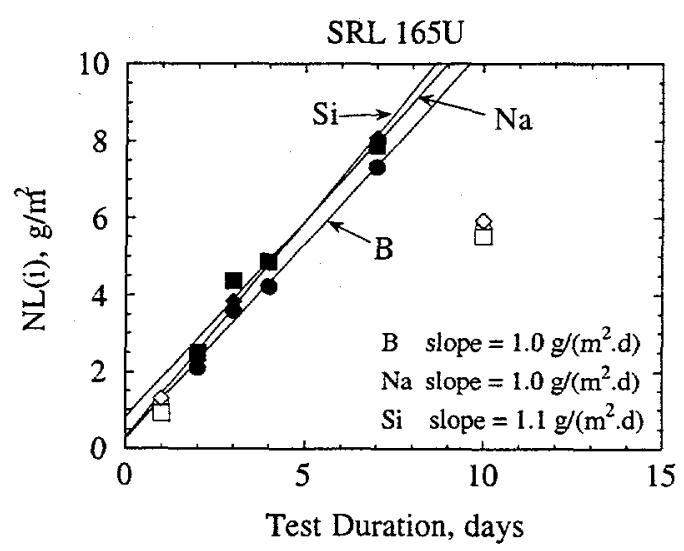

(c)

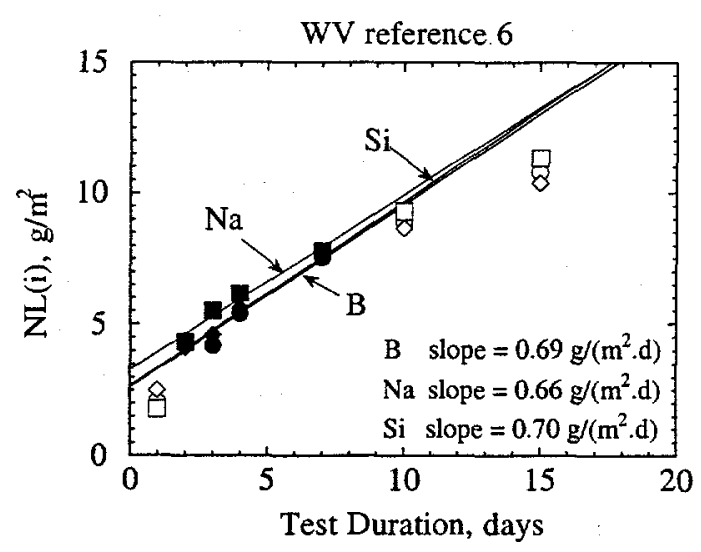

(e)

Fig. 1. Results of MCC-1 Tests with Reference High-Level Waste Glasses: (a) SRL 51S, (b) SRL 202U, (c) SRL 165U, (d) SRL 131U, (e) WV reference 6, (f) Hanford-D. Results shown by open symbols were excluded from regression analysis.

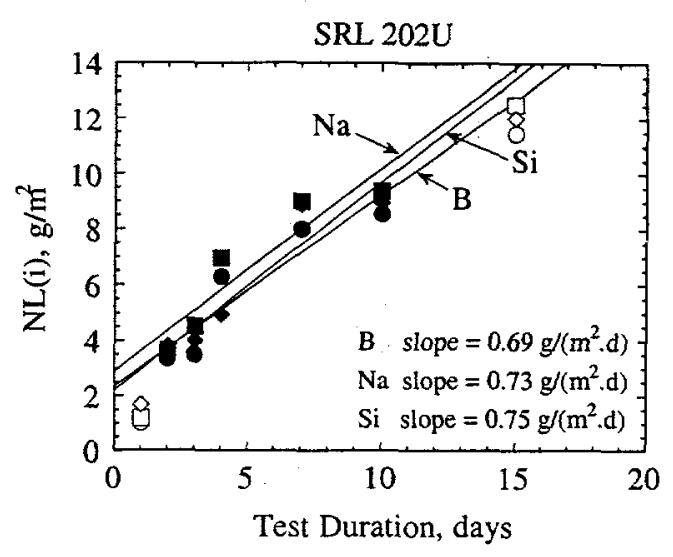

(b)

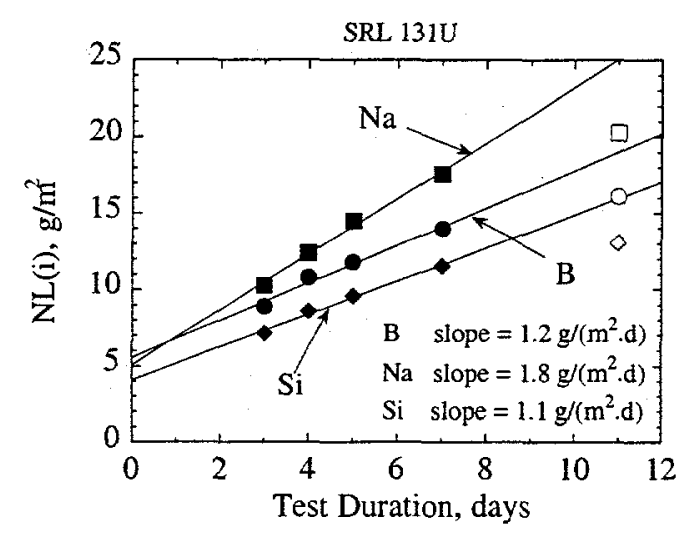

(d)

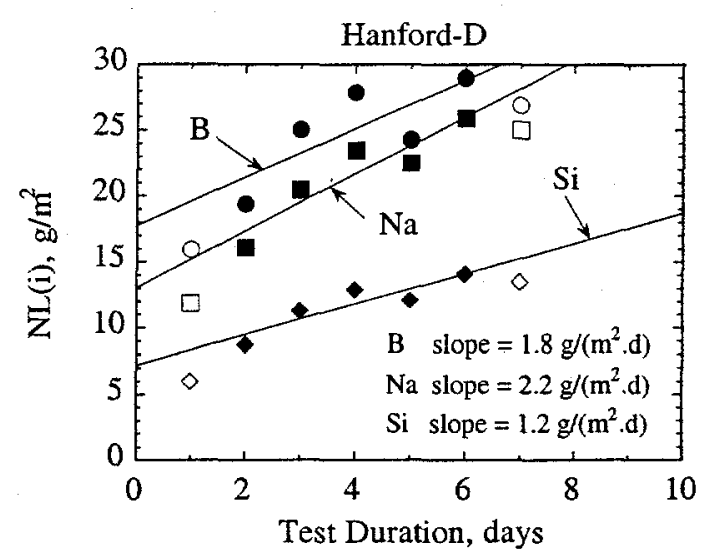

(f) 


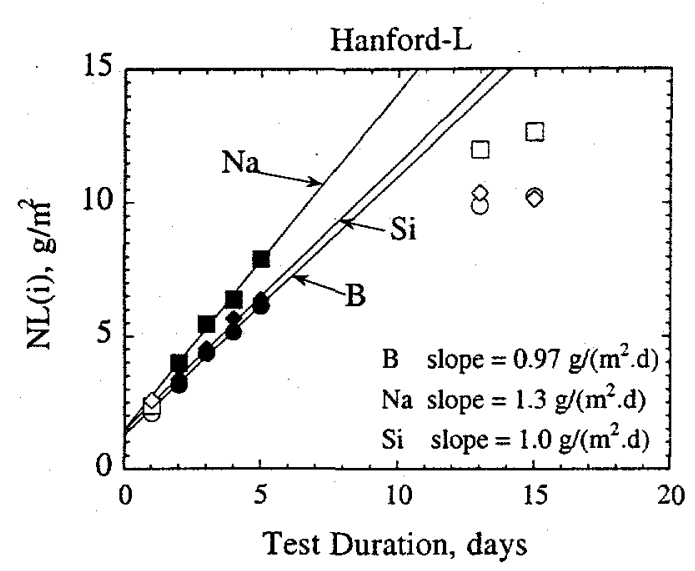

(a)

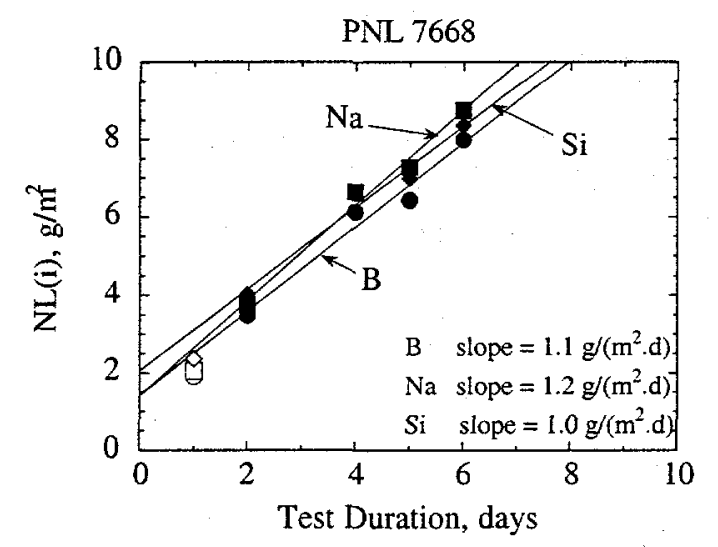

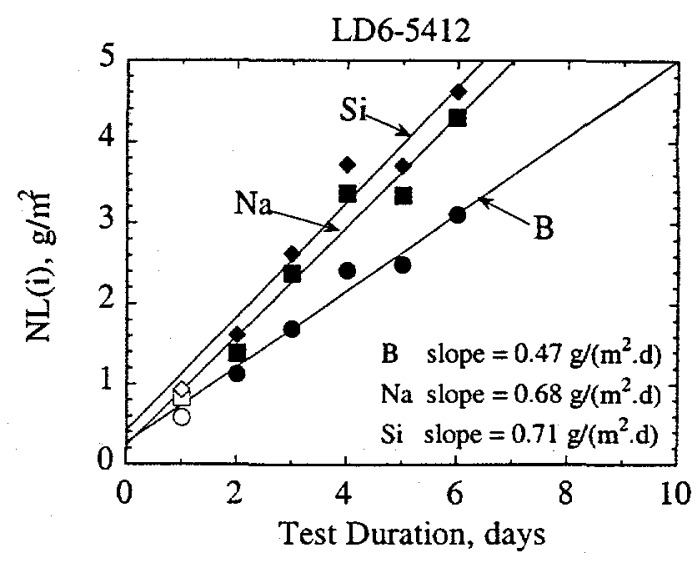

(b)

Fig. 2. Results of MCC-1 Tests with (a) Hanford-L, (b) LD6-5412, and (c) PNL 7668 Glasses. (O) NL(B), (ם) NL(Na), and $(\bullet)$ NL(Si). Results shown by open symbols were excluded from regression analysis.

(c)

difference in the dissolution rates of these glasses in short-term MCC-1 tests is due to the small differences in the solution $\mathrm{pH}$ values. A conservative upper bound for the intrinsic dissolution rate is the mean plus two standard deviations, which is $\log \left\{\mathrm{k}_{0} /\left[\mathrm{g} /\left(\mathrm{m}^{2} \bullet \mathrm{d}\right)\right]\right\}=8.5$ if the higher of the values based on boron or silicon is used. The forward dissolution rate at any temperature and $\mathrm{pH}$ can be calculated by using Eq. 1. This is the maximum possible dissolution rate of a waste glass under particular temperature and $\mathrm{pH}$ conditions. It is also the most conservative bound to the long-term corrosion rate of disposed high-level waste glasses. The similarity in the intrinsic dissolution rates of glasses having significantly different compositions is probably an indication that the same rate limiting reaction controls the dissolution rate for each glass. Secondary effects of the glass composition may become important as corrosion proceeds, such as the effect on the solution $\mathrm{pH}$ and the affinity term. These effects can dominant the glass response in other tests.

These results indicate that the intrinsic dissolution rate cannot be used to discriminate between glasses that have different chemical durabilities under anticipated disposal conditions. Instead, the response in a test that is sensitive to solution feedback effects must be used. We are currently evaluating the use of the product consistency test (PCT) for this purpose. 
Table 2. Summary of Normalized Dissolution Rates (NR) and Intrinsic Rate Constants

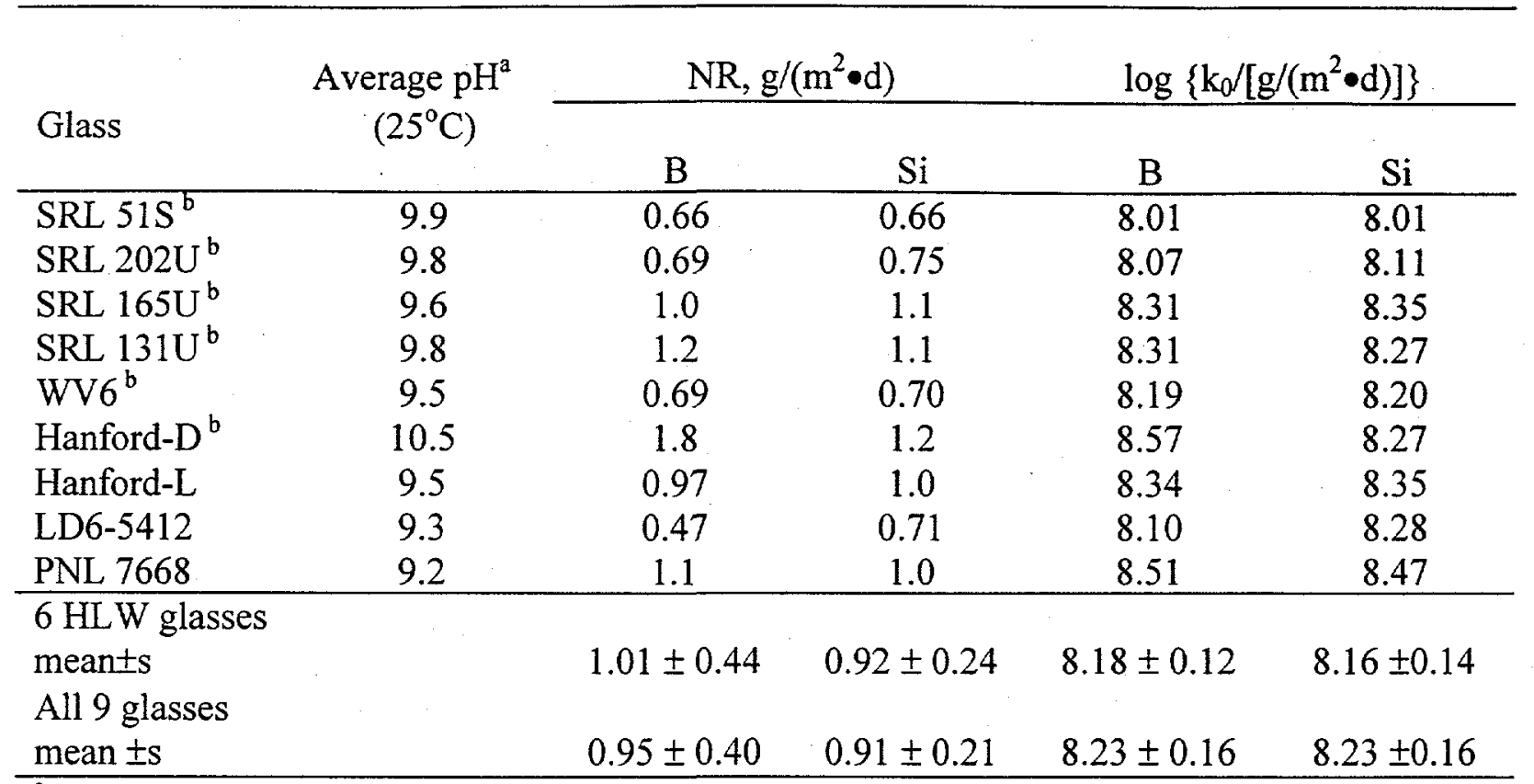

${ }^{\mathrm{a}}$ Average $\mathrm{pH}$ value measured at room temperature in tests included in regression.

${ }^{\mathrm{b}}$ Reference high-level waste glass.

CONCLUSIONS

The values of the intrinsic dissolution rates of nine borosilicate glasses having a wide range of compositions were estimated from the results of short-term MCC-1 tests by deconvoluting the effects of temperature and solution $\mathrm{pH}$. The intrinsic dissolution rates extracted from the results of tests were similar: $\log \left\{\mathrm{k}_{0} /\left[\mathrm{g} /\left(\mathrm{m}^{2} \bullet \mathrm{d}\right)\right]\right\}=8.2 \pm 0.2$. The very small variation in the determined rates indicates that the same intrinsic dissolution rate can be used for high-level waste glasses in performance assessment calculations with little added uncertainty. An upper bound for the intrinsic dissolution rates of borosilicate waste glasses can be assumed to be $\log \left\{\mathrm{k}_{0} /\left[\mathrm{g} /\left(\mathrm{m}^{2} \bullet \mathrm{d}\right)\right]\right\}=8.6$ at the $95 \%$ confidence limit.

\section{ACKNOWLEDGMENT}

Laboratory assistance provided by Jeffrey W. Emery, Lohman Hafenrichter, and Michael K. Nole. This task was performed under the guidance of the Yucca Mountain Site Characterization Project (YMP) and is part of activity D-20-28 in the YMP/Lawrence Livermore National Laboratory Spent Fuel Scientific Investigation Plan. This work was supported by the U. S. Department of Energy under contract W-31-109-ENG-38.

\section{REFERENCES}

1. "Total System Performance Assessment - Viability Assessment (TSPA-VA) Analyses Technical Basis Document: Waste Form Degradation," Chapter 6, Radionuclide Mobilization Preliminary, and Transport Through the Engineered Barrier System. Civilian Radioactive Waste Management System report B00000000-01717-4301-00004 REV 01, Las Vegas, Nevada, 1998. 
2. K. G. Knauss, W. L. Bourcier, K. D. McKeegan, C. I. Merzbacher, S. N. Nguyen, F. J. Ryerson, D. K. Smith, and H. C. Weed, in Scientific Basis for Nuclear Waste Management XIV, edited by V.M. Oversby and P.W. Brown (Mater. Res. Soc. Proc., 176, Pittsburgh, PA, 1990) pp. 371-381.

3. T. Advocat, J. L. Crovisier, E. Vernaz, G. Ehret, and H. Charpentier, in Scientific Basis for Nuclear Waste Management XIV, edited by T. Abrajano, Jr. and L.H. Johnson (Mater. Res. Soc. Proc., 212, Pittsburgh, PA, 1991) pp. 57-64.

4. B. P. McGrail, W. L. Ebert, A. J. Bakel, and D. K. Peeler, J. Nucl. Mat., 249, 175 (1997).

5. P. K. Abraitis, D. J. Vaughan, F. R. Livens, L. Monteith, D. P. Trivedi, J. S. Small, in Scientific Basis for Nuclear Waste Management XXI, edited by I. G. McKinley and C. McCombie (Mater. Res. Soc. Proc., 509, Pittsburgh, PA, 1998) pp. 47-54.

6. M.K. Andrews and N.E. Bibler, Ceram. Trans., Vol. 39, 205 (1993).

7. C. L. Crawford, D. M. Ferrara, B. C. Ha, and N. E. Bibler, in Proceedings of Spectrum '98, International Conference on Decommissioning and Decontamination and on Nuclear and Hazardous Waste Management, Denver, CO, September 13-18, La Grange Park, IL, 1998, pp. $581-588$.

8. Standard Test Method for Static Leaching of Monolithic Waste Forms for Disposal of Radioactive Waste, Standard C1220-98, American Society for Testing and Materials, West Conshohocken, PA. (1998).

9. C. Q. Buckwalter, L. R. Pederson, and G. L. McVay, J. Non-Cryst. Solids, 49 , 397-412 (1982). 